\title{
PROTOTYPE OF LINE FOLLOWER ROBOT APLIED TO INDUSTRIAL CUTTING OF TWO AXIS
}

\author{
Avalos Morín A. A. ${ }^{1^{*}}$; Rodríguez Ramírez N ${ }^{1}$, Mendoza Razo J. A. ${ }^{2}$ \\ 1 Metal-Mechanics Department, Instituto Tecnológico de San Luis Potosí, San Luis Potosí, México \\ 2 Electrics, Electronics and Mechatronics Department, Instituto Tecnológico de San Luis Potosí, San Luis Potosí, \\ México
}

*avalosmorin@gmail.com

\begin{abstract}
Currently, the geometric trajectory control of the most updated industrial machinery usually uses computer numerical control to perform complex cuts in two axis, demanding qualified operators in $\mathrm{G}$ and $\mathrm{M}$ programming language, which is characteristic of $\mathrm{CNC}$ equipment. The above features demand a hard economic investment and training. On the other hand, the semi-manual equipment is highly dependent on the operator and specialized
\end{abstract}

tooling, restricting portability and field complex activities. This paper shows part of methodology applied to the design of a prototype robot, which is based on infrared tracking of lines; a technique that has not been exploited in two dimensional production process. However, which counteracts issues such as low portability, limited intuition operating, high operation time and hard economic investment.

KEYWORD: Following line robot, Two axis cutting, Industrial cutting, Methodology of design 


\section{INTRODUCTION}

In the current estate of the art to achieve pieces with complex flat geometry, according to the compilation of some patents and industrial designs (SANDOVAL ROCHA E. et al, 2016; PLASCENCIA MORA H. et al, 2016; NUMERIK S.R.L., 2016; TECNOIMPORTADORA DE MAQUINARIA S.A. DE C.V., 2015), the commercial machinery usually employs computerized systems of motion to cut several materials such as metals, polymeric foams, solid ceramics, woods, among others. These require a high investment for acquisition and specialized training in $\mathrm{G}$ and $\mathrm{M}$ language programming, adding a careful handling of the computational system. During the operation of equipment, the most remarkable feature is the immobility of the machine structure, were it keeps motionless while a tool moves to make the cut, Figures 1 and 2 show some examples. This gives a low flexibility and no portability to perform outside activities. As well as, the restrictive disadvantage in processing large dimensions of material.

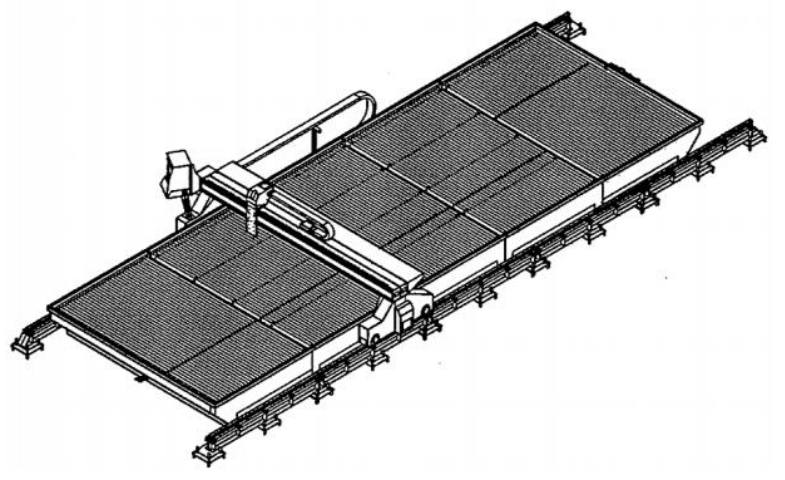

Figure 1: CNC industrial pantograph for cutting plates by oxyfuel, (SANDOVAL ROCHA E. et al, 2016) .

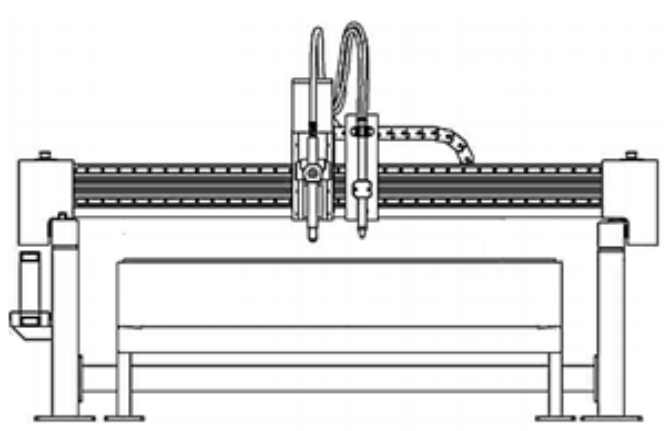

Figure 2: CNC industrial pantograph for cutting plates by plasma, (PLASCENCIA MORA H. et al, 2016).

On the other hand, the industrialized portable devices are manual or semiautomatic, were tasks are highly dependent on operator skills and specialized tooling, according to some industrial products (KOIKE ARONSON INC, 2017; FRANCO F., 1929). That consumes considerable preparation time, limiting to make only simple works. The figures 3, 4 and 5 show some of the most requested semiautomatic industrial cutting devices.

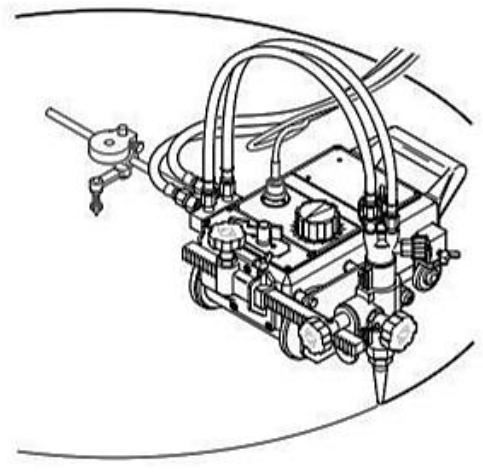

Figure 3: Semiautomatic cutting carriage on a guide for circular pieces, (KOIKE ARONSON INC., 2016).
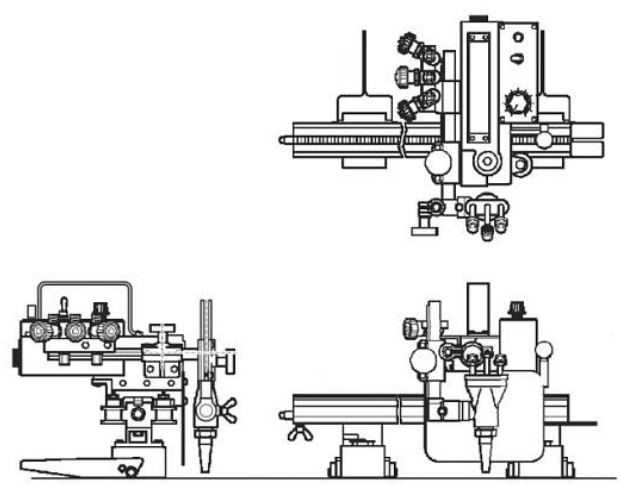

Figure 4: Semiautomatic carriage for straight cuts guided by rails, (KOIKE ARONSON INC., 2016) 


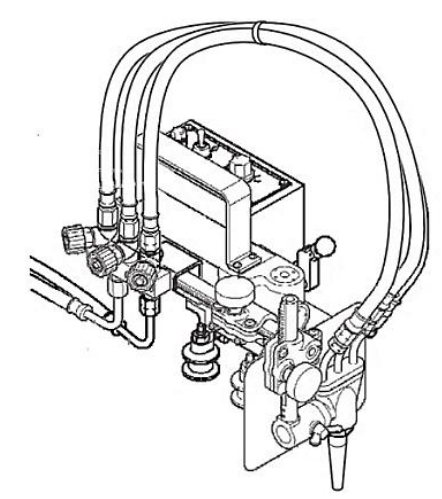

Figure 5: Carriage guided by rails and rollers for straight cuts, (KOIKE ARONSON INC., 2016).

\subsection{Nomenclature}

\begin{tabular}{|c|c|c|c|c|c|}
\hline Symbol & Units & Description & Symbol & Units & Description \\
\hline$\Delta Q$ & $\mathrm{~kJ}$ & Heat energy variation. & $\Delta t$ & $\mathrm{~s}$ & Time variation. \\
\hline$\Delta U$ & $\mathrm{~kJ}$ & $\begin{array}{l}\text { Internal energy } \\
\text { variation. }\end{array}$ & $d t$ & $\mathrm{~s}$ & Time differential. \\
\hline$\Delta W$ & $\mathrm{~kJ}$ & Thermal work variation. & $t_{1}$ & $\mathrm{~s}$ & Initial time. \\
\hline$Q_{E}$ & $\mathrm{~kJ}$ & Input heat energy. & $t_{2}$ & $\mathrm{~s}$ & Final time. \\
\hline$Q_{s}$ & $\mathrm{~kJ}$ & Output heat energy. & $\rho$ & $\mathrm{kg} / \mathrm{m}^{3}$ & Density. \\
\hline$\Delta H$ & $\mathrm{~kJ}$ & Enthalpy variation. & $v$ & $\mathrm{~m}^{3}$ & Volume. \\
\hline$C_{p}$ & $\mathrm{~kJ} / \mathrm{kg}-\mathrm{K}$ & $\begin{array}{l}\text { Specific heat capacity at } \\
\text { constant pressure. }\end{array}$ & $D$ & $\mathrm{~m}$ & Diameter. \\
\hline$m$ & $\mathrm{Kg}$ & Mass. & $L$ & $\mathrm{~m}$ & Length. \\
\hline$\Delta T$ & $\mathrm{~K}$ & Temperature variation. & $W_{\text {Elec }}$ & $\mathrm{kW}$ & Electrical power. \\
\hline$d T$ & $\mathrm{~K}$ & $\begin{array}{l}\text { Temperature } \\
\text { differential. }\end{array}$ & $V$ & $\mathrm{~V}$ & Voltage \\
\hline$T_{1}$ & $\mathrm{~K}$ & Initial Temperature. & $I$ & A & $\begin{array}{l}\text { Electrical current } \\
\text { intensity. }\end{array}$ \\
\hline$T_{2}$ & $\mathrm{~K}$ & Final Temperature. & $\mathrm{R}$ & $\Omega$ & Electrical resistance. \\
\hline$Q_{E}$ & $\mathrm{~kW}$ & Thermal Power. & & & \\
\hline
\end{tabular}




\subsection{Problem statement}

The previous areas of opportunity motivated to develop a portable system able to make cuts on solid surfaces. Below, it is shown part of methodology for portable device design, that initially was focused on the straight and square cutting of expanded polystyrene sheets; moving autonomously through flat surfaces (two axis) and following a physical trajectory (black line). Thus, covering features as portability, management intuition, preparation time, dependence on tooling and economic investment.

\section{MATERIAL AND METHODS}

Nowadays, line follower robots have not been highly exploited at industrial level, being restricted almost exclusively to academic competitions. However, it is a convenient option as a principle of operation to cut complex trajectories, due to simplicity of construction and low acquisition cost. The line follower robots are equipped with infrared sensors, which vary their nominal voltage when going from reflecting to non-reflective surfaces, Figure 6 . This variation is interpreted by an electronic controller, which governs the movement of the robot.

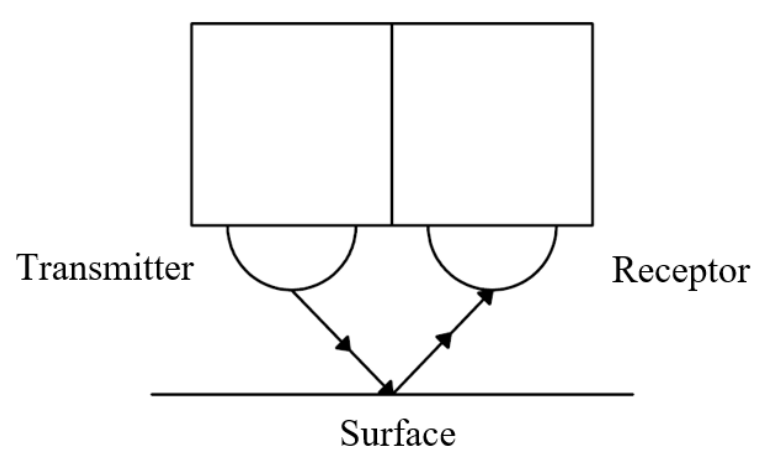

Figure 6: Reflective sensor or infrared sensor.

Base on this principle, the conception of the device follows the next design methodology (ULRICH K. T. et al, 2011):

- Define problem statement.

- Review state of the art.

- Build diagram of functions.
- Solve technical structures.

- Draw sketch design.

- Calculate designs.

\subsection{Function diagram}

Considering the operation and structure of some similar products, the function diagram for the prototype is elaborated, Figure 7. 


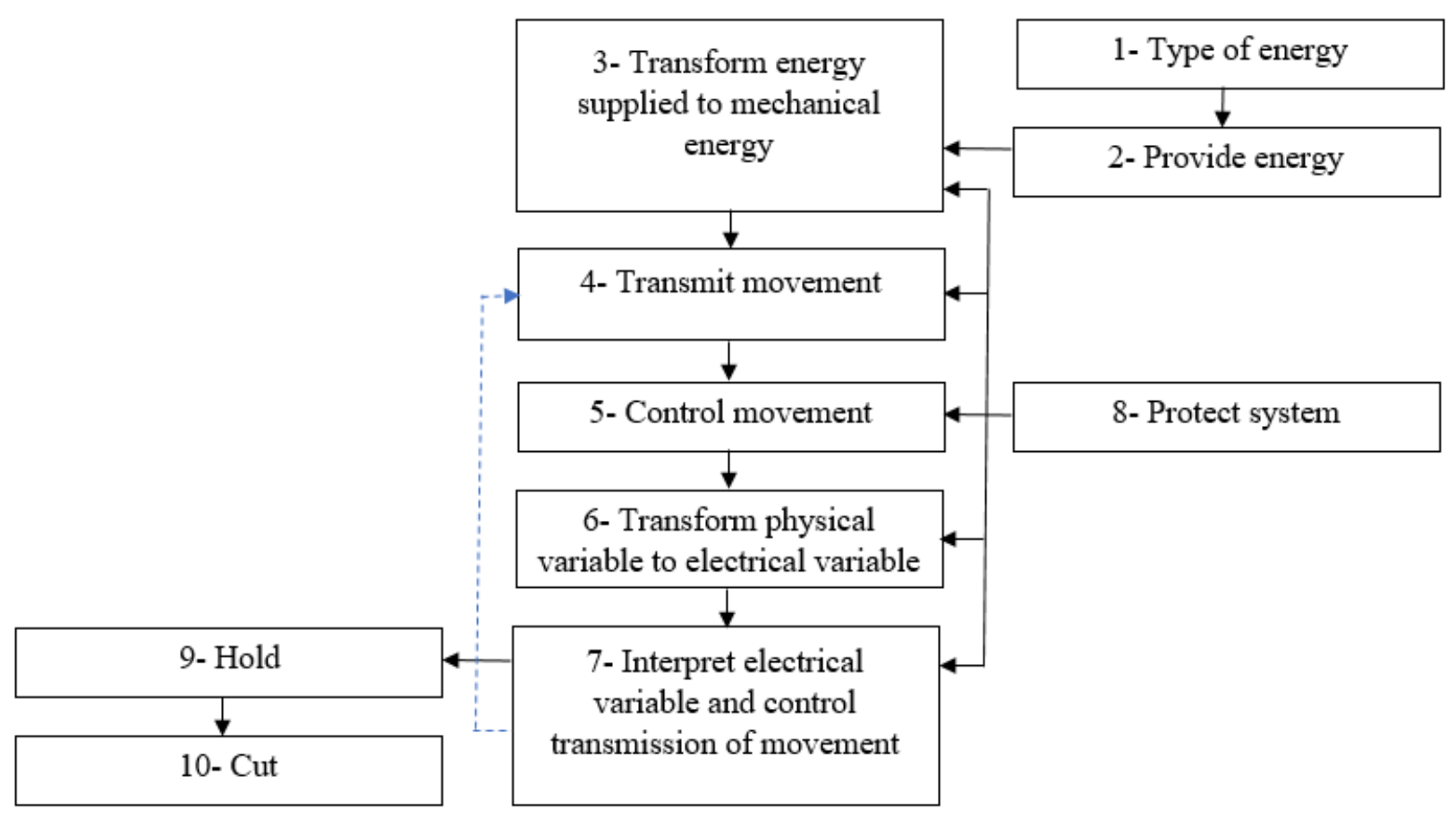

Figure 7: Function diagram for polymeric foams cutting.

\subsection{Solution of function diagram}

The function diagram, Figure 7, is composed by partial functions, which are necessary to achieve the main objective of the device. Each partial function is solved by capable technical structures to carry out the activities. Accordingly, several alternatives are proposed and evaluated to satisfy individual activities. To illustrate this section, the partial function 4 is taken, which transmits movement and displacement. The alternatives are: conventional wheels, omnidirectional wheels and mecanum wheels, Figures 8, 9 and 10, respectively.
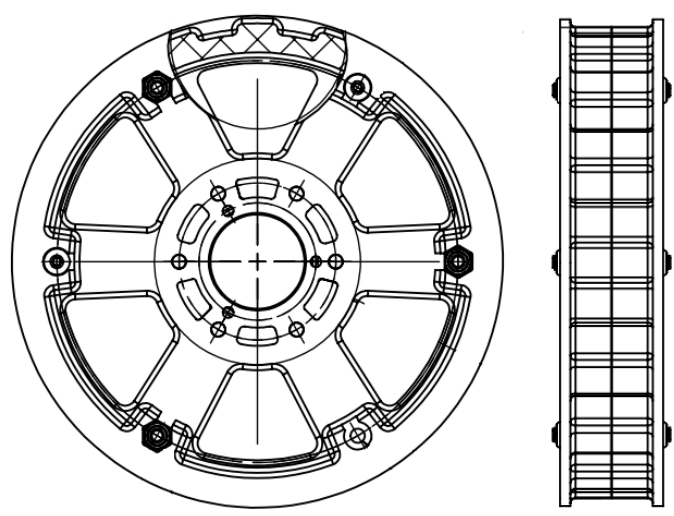

Figure 8: Alternative A - Conventional wheel, main and side views.

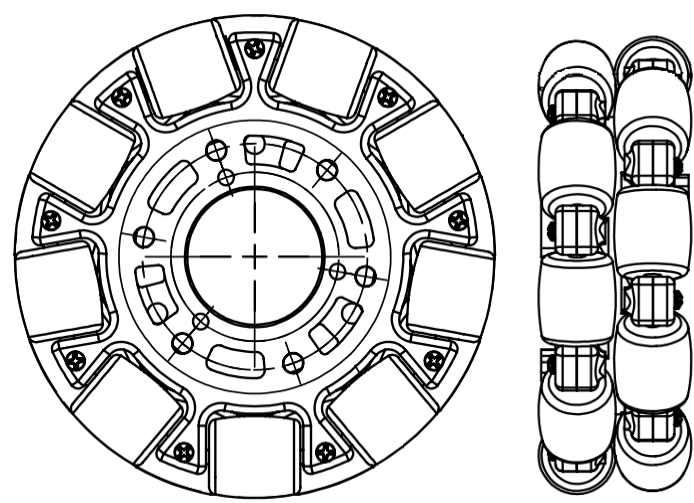

Figure 9: Alternative B - Omnidirectional wheel, main and side views. 


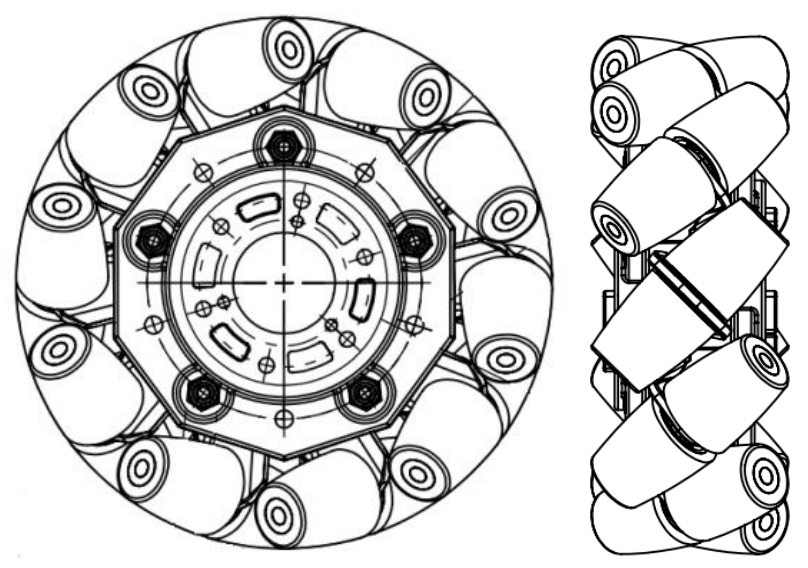

Figure 10: Alternative $C$ - Mecanum wheel, main and side views.

To select technical structures from alternatives, it used an evaluation matrix. However, previously the possible solutions are examined with advantages and disadvantages, Table 1.

Table 1: Advantages and disadvantages of alternatives, partial function 4.

\begin{tabular}{|c|c|c|}
\hline Alternatives & Advantages & Disadvantages \\
\hline \multirow[t]{4}{*}{$\mathrm{A}$} & Low acquisition cost. & Many adaptive elements for operation. \\
\hline & & Expensive adaptive elements. \\
\hline & & Low flexibility for new future functions. \\
\hline & & $\begin{array}{l}\text { Complicated maintenance due to many } \\
\text { adaptive elements. }\end{array}$ \\
\hline \multirow[t]{3}{*}{$\mathrm{B}$} & Moderate flexibility for new future & High acquisition cost. \\
\hline & functions. & Low flexibility for new future functions. \\
\hline & & $\begin{array}{l}\text { Complicated maintenance due to many } \\
\text { adaptive elements. }\end{array}$ \\
\hline \multirow[t]{2}{*}{$\mathrm{C}$} & Flexibility for new future functions. & High acquisition cost. \\
\hline & Few adaptive elements for operation. & \\
\hline
\end{tabular}

According to Table 1, the evaluation matrix is constructed, Table 2.

Table 2: Evaluation matrix of alternatives, partial function 4.

\begin{tabular}{clll}
\hline Evaluation criteria / Alternative & A & B & C \\
\hline Low acquisition cost. & 3 & 2 & 1 \\
\hline Few adaptive elements for operation. & 1 & 2 & 3 \\
\hline Low cost adaptive elements. & 1 & 2 & 3 \\
\hline Easy maintenance. & 2 & 2 & 3 \\
\hline High flexibility for new future functions. & 1 & 2 & 3 \\
\hline Total: & 8 & 10 & 13
\end{tabular}


The score is assigned according Table 3.

Table 3: References for evaluation.

\begin{tabular}{ccc}
\hline Complies & $\begin{array}{c}\text { Moderately } \\
\text { complies }\end{array}$ & $\begin{array}{c}\text { Does not } \\
\text { comply }\end{array}$ \\
\hline 3 & 2 & 1 \\
\hline
\end{tabular}

The best alternative is $\mathrm{C}$. Following the same procedure, the rest of the partial functions are solved, resulting the next diagram, Figure 11.

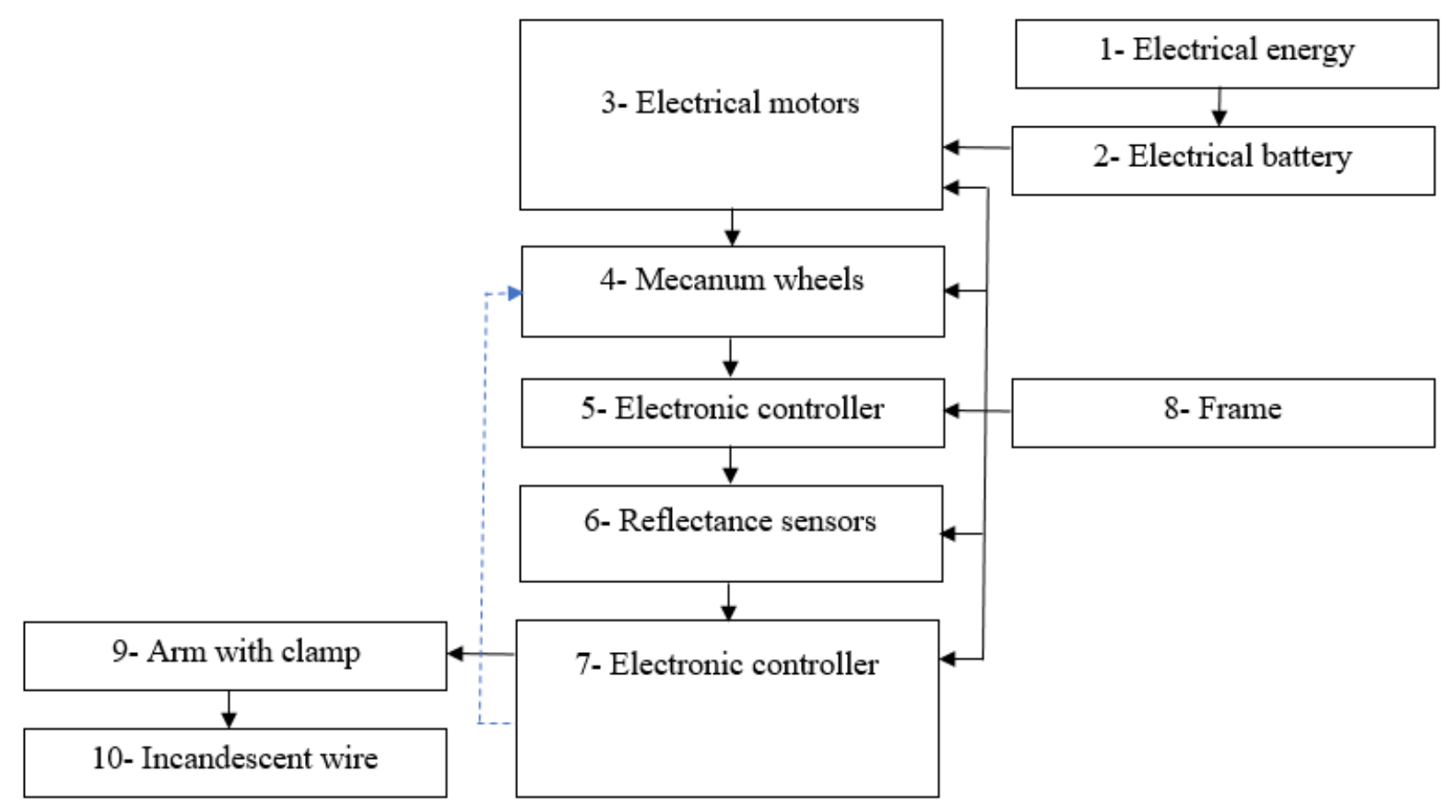

Figure 11: Function diagram with technical structures.

\section{RESULTS}

The sketch shown in Figures 12 and 13 is constructed from the diagram in Figure 11. 


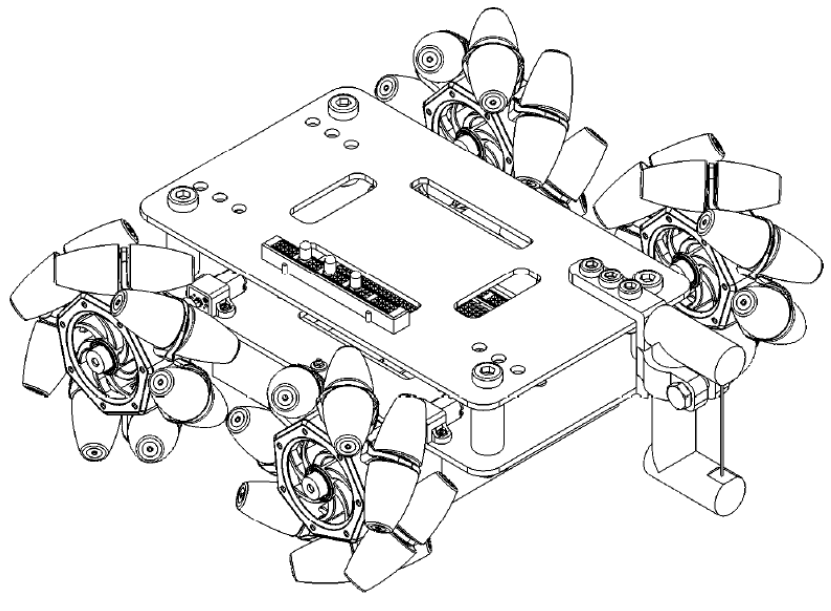

Figure 12: Conceptual sketch of portable system for polymeric foams cutting.

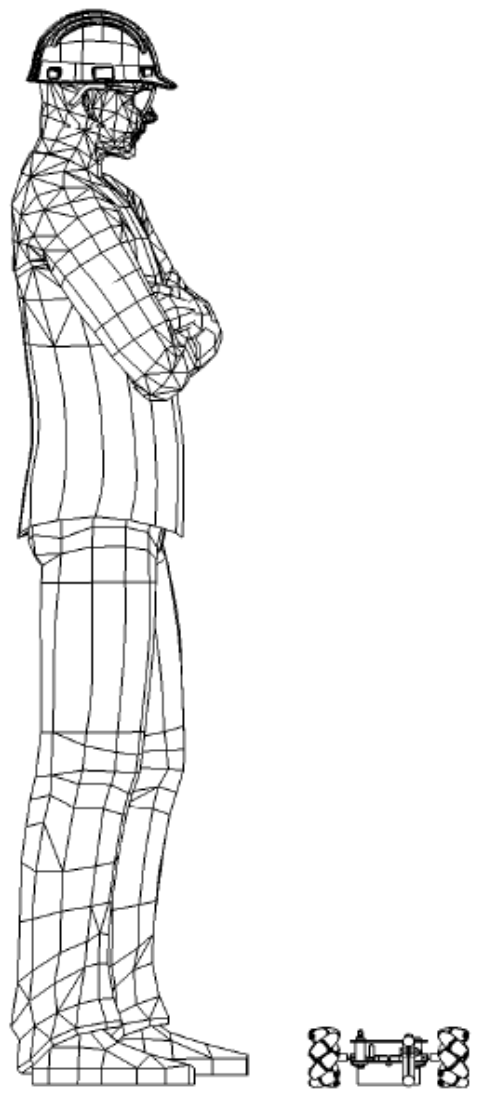

Figure 13: Conceptual sketch of portable system for polymeric foams cutting, with scale reference.

\subsection{Selection of particularities and design calculations}

Below, there are some selections and calculations made during the methodological design procedure. It is worth mentioning that they are not the only ones. However, the most significant of the development are exposed.

\subsubsection{Calculation of electrical potential for incandescent filament}

Expanded polystyrene is a thermoplastic polymer, which its viscoelastic behavior depends on temperature (KALPAKJIAN S. et al, 2014; GROOVER M. P., 2010). Accordingly, the separation of material by metallic filaments at temperatures over the melting range is possible. Table 4 contains some thermomechanical and thermochemical polystyrene properties.

Table 4: Thermomechanical and thermochemical properties of expanded polystyrene, (KALPAKJIAN S. et al, 2014; GROOVER M. P., 2010).

\begin{tabular}{cr}
\hline Melting range & Inflammation temperature \\
\hline $100^{\circ} \mathrm{C}-135^{\circ} \mathrm{C}$ & $400{ }^{\circ} \mathrm{C}-500^{\circ} \mathrm{C}$ \\
\hline
\end{tabular}


It is proposed to supply direct current from an electric battery so that the filament reaches the right temperature, Figure 14.

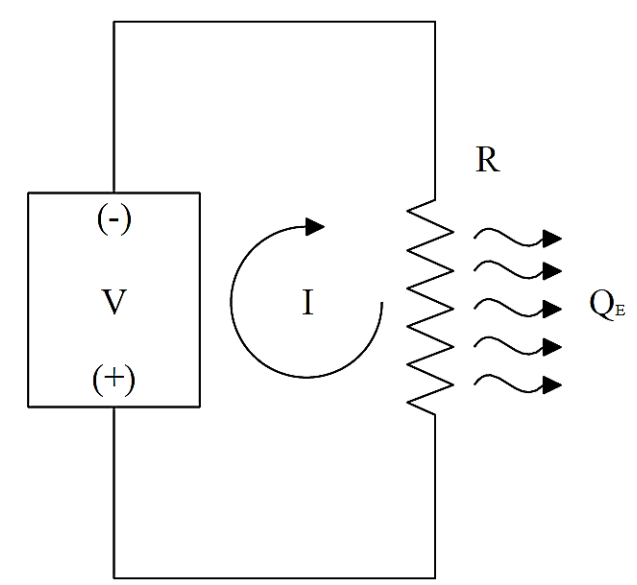

Figure 14: Electrical circuit for the incandescent filament.

Nichrome wire is selected for the filament; a nickel-chrome alloy commonly used in manual cutters to process extruded and expanded polystyrene. Table 5 shows some of the physical and thermomechanical properties of nichrome, $80 \%$ nickel $20 \%$ chromium.

Table 5: Physical and thermomechanical properties of the 80-20 nichrome wire, (ALLOW WIRE INTERNATIONAL, 2017)

\begin{tabular}{cc}
\hline Physical and thermomechanical properties & Numerical value \\
\hline Density at $20^{\circ} \mathrm{C}$ & $8300 \mathrm{~kg} / \mathrm{m}^{3}$ \\
\hline Melting temperature & $1400^{\circ} \mathrm{C}$ \\
\hline Maximum operating temperature & $1200^{\circ} \mathrm{C}$ \\
\hline Specific heat at constant pressure and $20^{\circ} \mathrm{C}$ & $0.45 \mathrm{~kJ} / \mathrm{kg}-\mathrm{K}$ \\
\hline
\end{tabular}

In order to know the adequate electrical power to supply the battery, it begins with an energy balance adding the first law of thermodynamics, eq. (1) y (2).

$$
\begin{gathered}
\Delta Q=\Delta U+\Delta W \\
\Delta Q=Q_{E}-Q_{\Delta}=\Delta H
\end{gathered}
$$

Where the enthalpy, as a general definition is equal to the product between specific heat at constant pressure, mass and temperature variation, eq. (3):

$$
Q_{R}-Q_{s}=\Delta H=C_{n} m \Delta T
$$


If $50 \%$ of input heat energy is lost as output heat energy due to thermal contact of the wire with the environment, it obtains eq. (4) and (5):

$$
\begin{gathered}
Q_{\Xi}=\frac{1}{2} Q_{E} \\
Q_{E}-\frac{1}{2} Q_{E}=\frac{1}{2} Q_{E}=C_{p} m \Delta T
\end{gathered}
$$

The eq. (5) can be rewritten and solved from an initial state 1 to a final state 2, eq. (6):

$$
Q_{E}=2 C_{p} m \int_{1}^{2} d T=C_{p} m\left(T_{2}-T_{1}\right)
$$

On the other hand, thermal power is defined as the quantity of heat energy transferred per unit time. Therefore, the thermal rate of the incandescent wire is:

$$
\dot{Q}_{E}=\frac{Q_{E}}{\Delta t}
$$

Eq. (8) is obtained by isolating and rewriting heat energy from eq. (7). Now, solving eq. (8) from an initial state 1 to a final state 2 it is obtained eq. (9).

$$
\begin{gathered}
Q_{E}=\dot{Q}_{E} \Delta t=\dot{Q}_{E} \int_{1}^{2} d t \\
Q_{E}=\dot{Q}_{E}\left(t_{2}-t_{1}\right)
\end{gathered}
$$

The density is described by eq. (11). Therefore, the mass is equal to eq. (12):

$$
\begin{gathered}
\rho=\frac{m}{v} \\
m=\rho v
\end{gathered}
$$

Where the wire volume can be calculated by eq. (13):

$$
v=\frac{\pi D^{2}}{4} L
$$

With eqs. (12) and (13) is obtained eq. (14). 


$$
m=\rho \frac{\pi D^{2}}{4} L
$$

According to the principle of energy conservation, the following eq. can be established:

$$
\dot{Q}_{E}=\dot{W}_{\text {Elec }}
$$

Where the electrical power is equal to the product between the current intensity and the circuit voltage:

$$
\dot{W}_{\text {Elec }}=V I
$$

With eqs. (10), (13) and (15) is obtained eq. (17):

$$
\dot{W}_{\text {Elec }}=V I=\frac{\rho C_{p} \pi D^{2} L\left(T_{2}-T_{1}\right)}{2\left(t_{2}-t_{1}\right)}
$$

Considering $L=50 \mathrm{~mm}=0.05 \mathrm{~m}, D=0.5 \mathrm{~mm}=0.0005 \mathrm{~m}, \quad t_{1}=0 \mathrm{~s}, t_{2}=12 \mathrm{~s}, T_{1}=20^{\circ} \mathrm{C}=$ $293.15^{\circ} \mathrm{K}$, y $T_{2}=160{ }^{\circ} \mathrm{C}=433.15^{\circ} \mathrm{K}$ (technical characteristics):

$$
\dot{W}_{\text {Elec }}=\frac{(8300)(450) \pi(0.0005)^{2}(0.05)(433.15-293.15)}{2(12-0)}=0.85 \mathrm{~W}
$$

Accordingly, direct current by cell phone charger (5 V and $180 \mathrm{~mA}$ output) is sufficient.

$$
\dot{W}_{\text {Elec }}=(5)(0.18)=0.9 \mathrm{~W} \approx 0.85 \mathrm{~W}
$$

\subsubsection{Logic of reflective sensors}

The geometric arrangement proposal for reflective sensors (numbered from 1 to 12 ) is shown in Figure 15. 


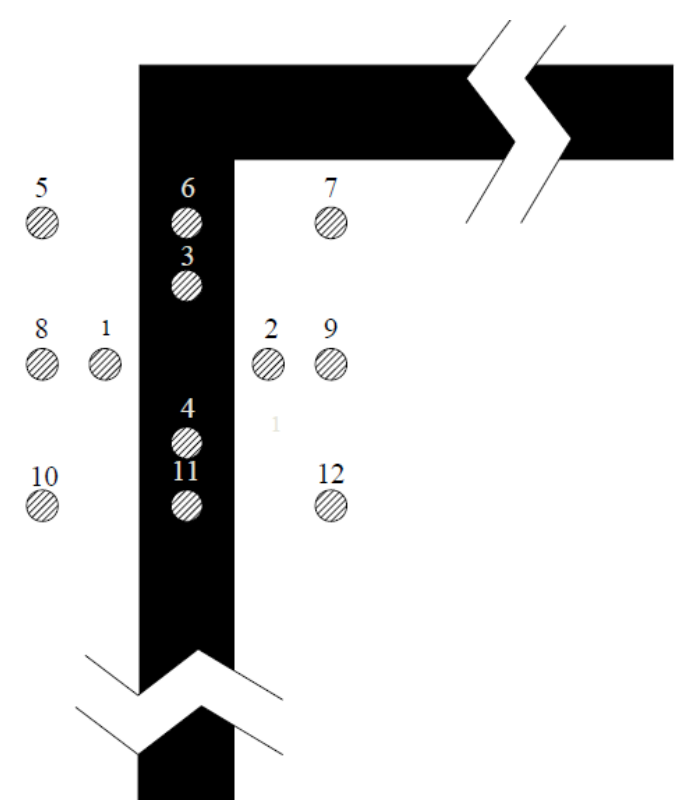

Figure 15: Arrangement of 12 reflective sensors for black line tracking.

Part of programming logic is explained below:

- If 1 and 2 are in white surface: continue moving in $90^{\circ}$ direction $(\uparrow)$; keep activated 5 and 7 ; keep deactivated 3, 4, 6, 8, 9, 10, 11 and 12 .

- If 1 is in white surface and 2 is in black surface: move in $45^{\circ}$ direction $(\uparrow+\rightarrow)$; keep activated 5 and 7; keep deactivated 3, 4, 6, 8, 9, 10, 11 and 12 .

- If 1 is in black surface and 2 is in white surface: move in $135^{\circ}$ direction $(\uparrow+\leftarrow)$; keep activated 5 and 7; keep deactivated 3, 4, 6, 8, 9, 10, 11 and 12 .

- If 7 detects black surface: continue moving in $90^{\circ}$ direction $(\uparrow)$; activate 9 ; keep activated 1,2 , and 5; keep deactivated 3, 4, 6, 8, 10, 11 and 12 .

- If 9 detects black surface; change movement in $0^{\circ}$ direction $(\rightarrow)$; activate 3,4 and 12 ; deactivate 1, 2, 5, 9; keep activated 7; keep deactivated 6, 8, 10 and 11 .

\section{CONCLUSIONS}

Starting from the design methodology, the objective selection of various alternatives was reached. Based on the above, a conceptual sketch was obtained. Subsequently, calculations were made to obtain the detailed design, Figure 16.
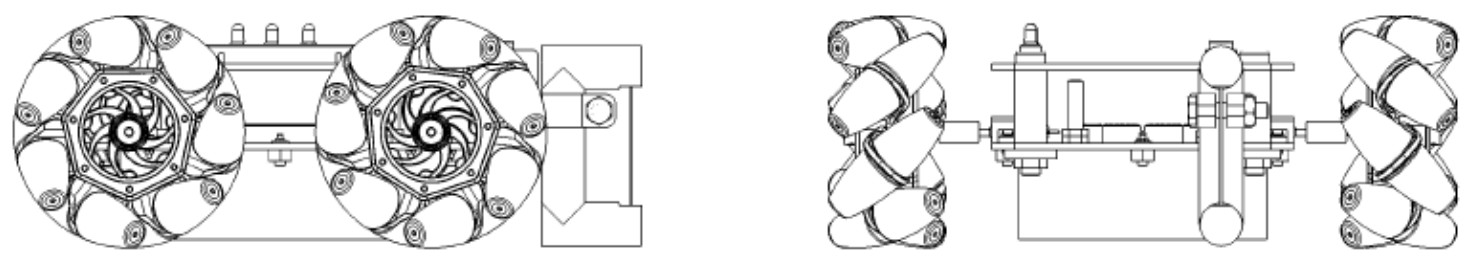

Figure 16: Detailed design of portable system for expanded polystyrene cutting, main view and side view. 
Currently, several tests based on factorial experiments have been carried out to evaluate the performance of the prototype. In the same way, the patent registration of the device and its derivatives has been initiated to protect intellectual property. The above is not limited to the polymeric foams cutting, the development includes the ability to cut in other materials by oxyfuel, plasma and laser. However, they are in experimental stages.

\section{Acknowledgments}

The authors acknowledge their families, friends and Instituto Tecnológico de San Luis Potosí. In the same way, it is made a special recognition to the following students: Juan Carlos Gonzáles Esquivel, Miguel Ángel Villaseñor López, Paola Razo Castañeda and Carlos Uriel Reyes Almendariz.

\section{REFERENCES}

ALlOW WIRE INTERNATIONAL, Alambre de resistencia Níquel-Cromo RW 80 Chrome 80. Available on: <http://www.alloywire.com/spanish/products_RW80_Nichrome_80.html>. Access on: January 2, 2017.

FRANCO F. Máquina cortadora de metales denominada “OXIGRAFO”. Public domain patent. Mexico. Application date: January 2, 1929. Concession date: December 31, 1929.

GROOVER, M. P. Principles of Modern Manufacturing. 4th. ed. U.S.A.: Prentice Hall, 2010.

KALPAKJIAN, S., SCHMIND, S. R. Manufacturing Engineering and Technology. 7th. ed. U.S.A.: Prentice Hall Pearson, 2014.

KOIKE ARONSON INC. Portable circle cutting machine, Data sheet: CIR CUT-II model. Switzerland: 2017.

KOIKE ARONSON INC. Portable shape cutting machine, Data sheet: IK-82. Switzerland: 2017.

KOIKE ARONSON INC. The portable multi-purpose carriage. Data sheet: IK-12 MAX 3 model. Switzerland: 2017.

NUMERIK S.R.L. Máquina CNC para corte de chapas. Data sheet: 1515/1530 model by EASYCUT. Argentina: 2016.

NUMERIK S.R.L. Máquina CNC para corte por láser de fibra completamente cerrada con cambio de pallet. Data sheet. Argentina: 2016.

NUMERIK S.R.L. Pantógrafo CNC para corte por plasma. Data sheet: SmartCut Line, Argentina: 2016.

PLASCENCIA MORA H., CHAVEZ NOLASCO A., GONZALES TIERRABLANCA L. M. Pantógrafo portátil para corte de espumas poliméricas asistido por computadora. MX/a/2010/010320, Application date: September 22, 201. Concession date: March 01, 2016.

SANDOVAL ROCHA E., SANDOVAL ASCENCIO O. U. Modelo industrial de pantógrafo para corte por plasma. MX/f/2015/000312, Application date: January 30, 2015. Concession date: February 12, 2016.

TECNOIMPORTADORA DE MAQUINARIA, S.A. DE C.V. Electroerosionadora de molybdeno. Data sheet: DW35 model by ARISTECH. Mexico: 2015.

ULRICH, K. T., EPPINGER, S. V. Product design and development. 5th. ed. U.S.A.: Mc Graw-Hill, 2011. 